Vol. 3, No. 2, Juli 2019, 30-40

Available Online at https://ejournal.warmadewa.ac.id/index.php/kulturistik DOI: dx.doi.org/10.22225/kulturistik.3.2.1186

\title{
PENINGKATAN PEMAHAMAN ISI TEKS BERBAHASA INGGRIS MELALUI METODE COOPERATIVE INTE- GRATED READING AND COMPOSITION (CIRC) PADA SISWA KELAS XI IPA 3 SMA JEMBATAN BUDAYA
}

\author{
P.A. Angandari \\ Universitas Udayana \\ putu.angan@gmail.com
}

\begin{abstract}
ABSTRAK
Membaca adalah keterampilan yang harus dipelajari dan dianggap sebagai yang paling penting karena dapat memengaruhi kemampuan berbahasa lainnya, seperti menyimak, berbicara, dan menulis (Hibbard, 2003). Pemahaman bacaan ditandai dengan pesan yang merupakan unsur terpenting yang harus diketahui oleh siswa karena tujuan utama membaca adalah untuk mengetahui gagasan dan ide yang tertuang dalam bentuk tulisan (Alderson, 2000). Tujuan penelitian ini adalah untuk mengetahui kemampuan siswa dalam memahami isi teks bahasa Inggris sebelum dan setelah metode CIRC diterapkan di kelas XI IPA 3 SMA Jembatan Budaya dalam tiga aspek pemahaman, yaitu pemahaman terhadap isi bacaan, pemahaman terhadap kohesi leksikal, dan pemahaman terhadap kohesi gramatikal. Sumber data adalah siswa kelas XI IPA 3 SMA Jembatan Budaya yang berjumlah 24 peserta didik. Bentuk penelitian ini sendiri adalah sebuah penelitian tindakan kelas. Penelitian ini memiliki tiga tahapan, tahapan pertama yaitu pelaksanaan tes pratindakan yang digunakan untuk mengetahui kemampuan dasar siswa, siklus 1 dan siklus 2 untuk mengaplikasikan metode CIRC ini. Hasil analisis data dalam penelitian ini disajikan dalam bentuk tabel, grafik, dan penjelasan deskripsi. Setelah dilakukannya tahapan-tahapan tersebut, diperoleh hasil penelitian bahwa metode CIRC dapat meningkatkan kemampuan membaca teks bahasa Inggris kelas XI IPA 3 SMA Jembatan Budaya yang ditunjukkan pada nilai dalam grafik yang meningkat dimulai dari pre-test, siklus 1 dan siklus 2.
\end{abstract}

Kata kunci: teks, membaca, metode CIRC

\begin{abstract}
[Title: Improving the Comprehension of English Text Content Through Cooperative Integrated Reading and Composition (CIRC) Method in Grade XI Science 3 Jembatan Budaya Senior High School] Reading is a skill that should be learned also be considered as one of the most important skill because it can affect other skills (listening, speaking, and writing) (Hibbard, 2003). The main purpose of reading is to know the thoughts and ideas expressed in writing (Alderson, 2000). This study also aims to determine the ability of students in understanding English text before and after CIRC method applied in class XI IPA 3 SMA Jembatan Budaya by three aspects of comprehension, those are, the comprehension of text content, lexical cohesion comprehension, grammatical cohesion comprehension. The data source is the 24 students of class XI IPA 3 SMA Jembatan Budaya. Research was held by using classroom action research and consists of three stages; pre-action testing used to determine student's ability before the test, cycle 1 and cycle 2 to apply CIRC method. Data collection used four instruments; observation, documentation, test and questionnaire. Data analysis which appeared from the research are presented in the form of tables, graphs, and description descriptions. The results showed that CIRC
\end{abstract}


Vol. 3, No. 2, Juli 2019, 31

Available Online at https://ejournal.warmadewa.ac.id/index.php/kulturistik DOI: dx.doi.org/10.22225/kulturistik.3.2.1186

method can improve the reading ability of English of grade 11 IPA 3 SMA Jembatan Budaya. Progress of study is shown by score achievement from pre-test, cycle 1 until cycle 2.

Keywords: reading, text, CIRC method

\section{PENDAHULUAN}

Teks disebut juga sebagai rangkaian kata atau bacaan dengan isi tertentu ataupun kandungan naskah, muatan naskah, uraian yang memberikan informasi mengenai sesuatu yang disajikan dalam bentuk lisan/tertulis (Mulyani, 2009: 2). Luxemburg mendefinisikan teks juga sebagai ungkapan bahasa yang dilihat dari segi isi, sintaksis, dan pragmatik merupakan satu kesatuan (Luxemburg \& Et.al., 1992: 86). Teks juga dalam arti lain juga sebagai seperangkat tanda yang dipindahkan oleh seorang pengirim kepada seorang penerima melewati suatu medium atau suatu kode (Sobur, 2004: 53). Dalam buku Analisis Wacana disebutkan bahwa teks hampir sama juga dengan wacana, bedanya teks memang hanya dapat disampaikan dalam bentuk tulisan, namun wacana dapat disampaikan, baik dalam bentuk lisan maupun tertulis (Eriyanto, 2001: 3)

Pada umumnya beberapa teks ditemukan dalam pelajaran bahasa yang mengetengahkan keterampilan membaca. Membaca merupakan keterampilan yang harus dipelajari dan dianggap sebagai keterampilan yang paling penting karena dapat juga memengaruhi kemampuan berbahasa lainnya seperti menyimak, berbicara, dan menulis (Hibbard, 2003: 10). Membaca bisa juga dianggap sebagai suatu proses dinamis yang difungsikan untuk merekonstruksi suatu pesan yang secara grafis telah dikodekan oleh sang penulis. Pada proses mengkontruksi pesan penulis melakukan pengodean linguistik yang lalu pembaca uraikan sehingga pada akhirnya didapatkan makna dan pesan yang terkandung dalam bacaan (Goodman, 1996: 2 - 3).

Ada tujuh kriteria dalam teks. Salah satu di antaranya adalah kohesi yang berkaitan juga dengan komponen dan permukaan tekstual, yaitu berhubungan dengan sintaktis teks, rangkaian lingustik dalam suatu teks tidak pernah terjadi secara kebetulan, tetapi selalu memenuhi ketergantungan dan kaidah-kaidah dalam gramatikal. Seluruh fungsi yang digunakan dalam menciptakan hubungan di antara unsur-unsur permukaan dikategorikan sebagai kohesi. Salah satu langkah yang bias digunakan untuk mencapai kohesi adalah perulangan unsur leksikal (Titscher, 2009: 35).

Pemahaman bacaan ditandai dengan pesan yang disampaikan dalam bentuk tertulis. Pesan ini merupakan unsur terpenting yang harus diketahui oleh siswa karena tujuan utama membaca adalah untuk mengetahui pikiran dan ide yang dinyatakan dalam bentuk tulisan (Alderson, 2000: 2). Pembaca yang baik harus benar-benar memahami apapun bacaannya (Tarigan, 2008: 121).

Sebuah pengamatan yang dilakukan di salah satu sekolah swasta, yaitu SMA Jembatan Budaya, ditemukan bahwa minat membaca siswanya sangat kurang. Hal ini merupakan fenomena yang cukup mengusik peneliti karena pada Ujian Nasional (UN), soal Bahasa Inggris terdiri atasi $90 \%$ bacaan. Hal ini tentu saja akan menyulitkan siswa nantinya dalam mengerjakan soal Bahasa Inggris saat menjalani UN. Terkait fenomena tersebut, peneliti lalu mengadakan sebuah tes yang melatarbelakangi diadakannya penelitian lebih mendalam untuk peningkatan kemampuan membaca teks berbahasa Inggris melalui metode Cooperative 
Vol. 3, No. 2, Juli 2019, 32

Available Online at https://ejournal.warmadewa.ac.id/index.php/kulturistik DOI: dx.doi.org/10.22225/kulturistik.3.2.1186

Integrated Reading and Composition (CIRC) pada siswa kelas XI IPA 3 SMA Jembatan Budaya.

Pemecahan masalah pada penelitian dilakukan dengan penggunaan sebuah metode. Metode CIRC merupakan kependekan dari Cooperative Integrated Reading Composition, juga telah banyak membuktikan keberhasilannya dalam peningkatan kemampuan membaca.

Cooperative Integrated Reading and Composition (CIRC) adalah sebuah metode komprehensif dalam mengajarkan bidang studi membaca, menulis, dan seni berbahasa, terutama pada bacaan yang menggunakan bahasa asing seperti bahasa Inggris (Slavin, 2005: 200). Model pembelajaran kooperatif menyatukan sebuah bacaan secara menyeluruh dan lalu mengomposisikannya menjadi bagianbagian lain yang lebih penting (Sutarno \& Dkk, 2010: 1). Metode ini dikembangkan karena dipercaya dapat meningkatkan kemampuan peserta didik membaca dan menerima umpan balik dari kegiatan membaca yang telah dilakukan. Kegiatannya ini banyak mengandung pengaplikasian membaca dan menulis secara bersama-sama atau berkelompok karena akan menciptakan kondisi lingkungan belajar yang memiliki situasi dan kondisi dimana siswa bias menciptakan aktivitas untuk mereka sendiri (Arbainsyah, 2008: 70 - 71). Bekerja dalam kelompok akan lebih efektif dan efisien jika diterapkan dalam penelitian ini karena proses pembelajaran harus mendorong adanya kerja sama. Proses belajar yang mengandung nilai-nilai kerja sama memungkinkan murid dalam merekam memori pelajaran lebih lama (Carr, Jonassen, Litzinger, \& Marra, 1998: 8 - 9).

Penelitian ini dilakukan di sebuah sekolah menengah atas Jembatan $\mathrm{Bu}-$ daya. Dalam hal ini siswa kelas XI IPA 3 merupakan kelompok yang berperan dalam penelitian ini untuk memberikan dasar membaca pemahaman yang baik kepada siswa. Dengan demikian mereka tidak akan kaget menerima berbagai macam soal yang memiliki jumlah bacaan yang cukup banyak.

Latar belakang di atas akhirnya dapat merumuskan permasalahan sebagai berikut untuk mengetahui bagaimana kemampuan siswa dalam memahami kohesi leksikal pada teks berbahasa Inggris sebelum dan setelah metode CIRC diterapkan di kelas XI SMA Jembatan Budaya dan bagaimana kemampuan siswa dalam memahami kohesi gramatikal pada teks berbahasa Inggris sebelum dan setelah metode CIRC diterapkan di kelas XI SMA Jembatan Budaya.

Adapun tujuan penelitian ini, yaitu untuk memperbarui kajian dalam hal keterampilan membaca tentang peningkatan pemahaman teks berbahasa Inggris melalui metode CIRC. Pemahaman ini ditinjau dari sisi linguistik, yaitu kemampuan memahami kohesi leksikal dan kohesi gramatikal.

\section{METODE}

Lokasi penelitian adalah SMA Jembatan Budaya yang beralamat di Jalan Raya Kuta No. 1, yang merupakan batas wilayah Denpasar dan Kuta. Penelitian ini menggunakan pendekatan penelitian tindakan (action research) dengan metode yang digunakan adalah penelitian tindakan kelas (PTK) dimana pendekatan ini akan mengkaji data kuantitatif aspek lingustik terapan yaitu pembelajaran dan pengajaran bahasa di samping itu, juga mengkaji data kualitatif dari aspek linguistiknya, dalam hal ini kohesi leksikal dan kohesi gramatikal.

Data yang terdapat pada penelitian ini merupakan jenis data kualitatif dan data kuantitatif sebagai data penunjang. Data kualitatif diperoleh dari catatan penelitian selama penelitian berlangsung pada tiap siklusnya serta penjabaran 
Vol. 3, No. 2, Juli 2019, 33

Available Online at https://ejournal.warmadewa.ac.id/index.php/kulturistik DOI: dx.doi.org/10.22225/kulturistik.3.2.1186

hasil kuesioner sebelum dan sesudah penelitian berlangsung. Data kuantitatif diperoleh dari nilai hasil tes awal, nilai latihan tiap siklus, dan nilai akhir tes.

Penelitian ini menggunakan instrumen berupa kuesioner sederhana, tes, dan catatan penilaian. Selain partisipasi aktif siswa saat proses penelitian berlangsung berjalannya metode ini sangat bergantung kepada keaktifan siswa dalam menjalankan semua aturan dalam metode baru yang diberikan.

\section{PEMBAHASAN}

Data yang digunakan dalam penelitian ini didapatkan dari hasil tes siswa kelas XI IPA 3 SMA Jembatan Budaya. Tes yang diberikan berjumlah lima puluh soal pilihan ganda mengenai kohesi gramatikal, kohesi leksikal, dan pemahaman bacaan yang terdiri atas tujuh teks. Adapun pembagian soal, yaitu lima belas soal masing-masing mengenai kohesi gramatikal dan kohesi leksikal dan dua puluh soal mengenai pemahaman bacaan. Setelah data diperoleh, jawaban dikelompokkan berdasarkan kohesinya untuk memudahkan analisis data yang diperoleh.

Hasil tes referensi dan jenis-jenisnya ini dikelompokkan sesuai dengan kelompok referensinya masing-masing sehingga dapat diketahui bagaimana tingkat pemahaman peserta didik mengenai teks bahasa Inggris melalui metode CIRC. Setelah semua data mengenai tingkat pemahaman mahasiswa diketahui, selanjutnya referensi yang terdapat pada tiap-tiap teks dianalisis menggunakan teori kohesi Halliday dan Hasan untuk mengetahui jawaban tes yang diberikan.

Melalui pemaparan diagram berikut ditunjukkan pemahaman peserta didik mengenai teks bahasa Inggris melalui kemampuan menguasai kohesi gramatikal, kohesi leksikal, dan pemahaman tentang teks tersebut.

Kemampuan Siswa dalam Memahami Kohesi Leksikal dan Kohesi Gramatikal pada Teks Berbahasa Inggris Sebelum Metode CIRC Diterapkan di Kelas XI IPA 3 SMA Jembatan Budaya

Untuk memperoleh data penelitian tindakan kelas, peneliti digunakan tiga jenis instrument, yaitu pre-test, post-test, dan kuesioner. Data yang didapat digunakan untuk menjawab masalah melalui penguasaan instrumen yang telah disebutkan sebelumnya pada kelas XI IPA 3 SMA Jembatan Budaya.

Pre-test untuk pemahaman bacaan ditujukan kepada peserta didik untuk mengetahui kemampuan mereka memahami bacaan. Pada pre-test, peserta didik diberikan lima puluh soal pilihan ganda untuk menentukan kemampuan mereka memahami bacaan serta pemahaman terhadap kohesi leksikal dan gramatikal. Post-test dilakukan dalam dua siklus.

Tes awal diberikan dalam perannya untuk mengetahui kemampuan awal siswa dalam pemahaman terhadap suatu bacaan. Tes dilakukan dengan memberikan tugas menjawab lima puluh soal pilihan ganda yang terdiri atas aspek gramatikal, aspek leksikal, dan pemahaman bacaan. Pekerjaan peserta didik yang digunakan sebagai sumber data, dianalisis mengikuti aspek penilaian yang sudah dijelaskan pada bab sebelumnya. Berikut dideskripsikan hasil awal siswa daris egi kemampuan dalam memahami teks bahasa Inggris yang dikategorikan dalam tiga aspek penilaian dan disajikan dalam bentuk tabel. 


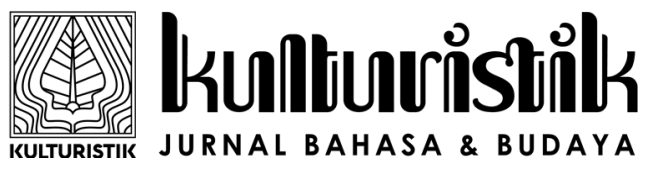

Vol. 3, No. 2, Juli 2019, 34

Available Online at https://ejournal.warmadewa.ac.id/index.php/kulturistik DOI: dx.doi.org/10.22225/kulturistik.3.2.1186

Tabel 1 Hasil Tes Pratindakan Membaca Pemahaman

\begin{tabular}{|c|c|c|c|c|c|c|}
\hline \multirow[b]{2}{*}{ No. } & \multirow[b]{2}{*}{ Nama } & \multicolumn{3}{|c|}{ Aspek } & \multirow[b]{2}{*}{ Skor } & \multirow[b]{2}{*}{ Nilai } \\
\hline & & Gramatikal & Leksikal & $\begin{array}{l}\text { Pemahaman ide } \\
\text { pokok bacaan }\end{array}$ & & \\
\hline 1. & $\mathrm{~S} 1$ & 11 & 14 & 17 & 42 & 84 \\
\hline 2. & $\mathrm{~S} 2$ & 11 & 12 & 17 & 40 & 80 \\
\hline 3. & S3 & 11 & 11 & 17 & 39 & 78 \\
\hline 4. & $\mathrm{~S} 4$ & 9 & 11 & 14 & 32 & 64 \\
\hline 5. & S5 & 10 & 13 & 15 & 37 & 74 \\
\hline 6. & S6 & 8 & 8 & 8 & 24 & 48 \\
\hline 7. & S7 & 8 & 8 & 9 & 25 & 50 \\
\hline 8. & S8 & 10 & 6 & 6 & 22 & 44 \\
\hline 9. & S9 & 9 & 6 & 8 & 23 & 46 \\
\hline 10. & S10 & 11 & 11 & 13 & 35 & 70 \\
\hline 11. & S11 & 13 & 13 & 11 & 37 & 74 \\
\hline 12. & $\mathrm{~S} 12$ & 11 & 11 & 15 & 34 & 68 \\
\hline 13. & $\mathrm{~S} 13$ & 12 & 13 & 16 & 40 & 80 \\
\hline 14. & S14 & 13 & 12 & 16 & 41 & 82 \\
\hline 15. & S15 & 11 & 12 & 16 & 39 & 78 \\
\hline 16. & S16 & 11 & 11 & 12 & 34 & 68 \\
\hline 17. & S17 & 13 & 8 & 11 & 32 & 64 \\
\hline 18. & S18 & 10 & 13 & 12 & 35 & 70 \\
\hline 19. & S19 & 11 & 11 & 16 & 37 & 74 \\
\hline 20. & S20 & 10 & 11 & 12 & 32 & 64 \\
\hline 21. & $\mathrm{~S} 21$ & 11 & 6 & 11 & 29 & 58 \\
\hline 22. & $\mathrm{~S} 22$ & 11 & 9 & 17 & 37 & 74 \\
\hline 23. & $\mathrm{~S} 23$ & 9 & 13 & 13 & 34 & 68 \\
\hline \multirow[t]{5}{*}{24.} & S24 & 12 & 9 & 13 & 34 & 68 \\
\hline & $\begin{array}{r}\text { Jumlah hasil } \\
\text { belajar }\end{array}$ & 256 & 252 & 315 & 814 & 1.628 \\
\hline & Rata-rata kelas & 10,67 & 10,5 & 13,12 & 34,29 & 68,58 \\
\hline & Nilai tertinggi & & & & & 84 \\
\hline & Nilai terendah & & & & & 44 \\
\hline
\end{tabular}

Hasil tes awal (pratindakan) yang dilakukan menunjukkan bahwa nilai ratarata kemampuan awal siswa dalam memahami teks berbahasa Inggris sebesar 68,58 . Pada tahap awal (pratindakan) diperoleh nilai minimal 44 dan nilai maksimal adalah 84 . Delapan belas orang siswa $(75 \%)$ bisa dikatakan belum mencapai nilai yang sesuai dengan kriteria ketuntasan minimal (KKM) dalam pelajaran bahasa Inggris, yaitu 75 dan hanya enam orang siswa (25\%) yang mampu mencapai nilai KKM, yaitu 75 ke atas. Dalam tes pratindakan yang dilakukan, dilihat dari hasil yang dicapai, siswa lebih banyak kurang paham dalam menguasai kohesi leksikal. Untuk itu, siswa perlu diberikan pemahaman yang lebih lagi dalam menguasai kohesi leksikal agar pada siklus 1 ataupun 2siswa dapat memahami bacaan dan menjawab soal dengan lebih baik lagi. 


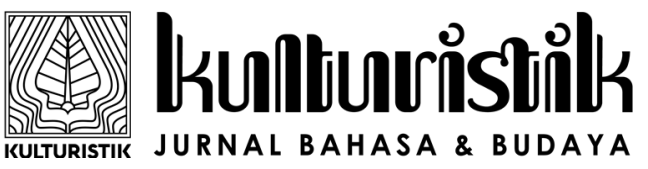

Vol. 3, No. 2, Juli 2019, 35

Available Online at https://ejournal.warmadewa.ac.id/index.php/kulturistik DOI: dx.doi.org/10.22225/kulturistik.3.2.1186

Tabel 2 Hasil Tes Evaluasi Belajar Siklus 1

\begin{tabular}{|c|c|c|c|c|c|c|}
\hline \multirow[b]{2}{*}{ No. } & \multirow[b]{2}{*}{ Nama } & \multicolumn{3}{|c|}{ Aspek } & \multirow[b]{2}{*}{ Skor } & \multirow[b]{2}{*}{ Nilai } \\
\hline & & Gramatikal & Leksikal & $\begin{array}{l}\text { Pemahaman ide } \\
\text { pokok bacaan }\end{array}$ & & \\
\hline 1. & S1 & 13 & 11 & 15 & 39 & 78 \\
\hline 2. & $\mathrm{~S} 2$ & 13 & 12 & 13 & 38 & 76 \\
\hline 3. & $\mathrm{~S} 3$ & 14 & 14 & 15 & 43 & 86 \\
\hline 4. & S4 & 12 & 14 & 11 & 37 & 74 \\
\hline 5. & S5 & 12 & 9 & 5 & 27 & 54 \\
\hline 6. & S6 & 13 & 11 & 15 & 39 & 78 \\
\hline 7. & S7 & 12 & 10 & 11 & 33 & 66 \\
\hline 8. & S8 & 13 & 11 & 14 & 37 & 74 \\
\hline 9. & S9 & 13 & 9 & 14 & 36 & 72 \\
\hline 10. & S10 & 13 & 13 & 17 & 43 & 86 \\
\hline 11. & $\mathrm{~S} 11$ & 13 & 13 & 11 & 36 & 72 \\
\hline 12. & $\mathrm{~S} 12$ & 12 & 12 & 10 & 39 & 78 \\
\hline 13. & S13 & 14 & 15 & 18 & 47 & 94 \\
\hline 14. & S14 & 14 & 12 & 16 & 42 & 84 \\
\hline 15. & $\mathrm{~S} 15$ & 14 & 13 & 12 & 39 & 78 \\
\hline 16. & S16 & 14 & 10 & 13 & 37 & 74 \\
\hline 17. & S17 & 14 & 14 & 14 & 42 & 84 \\
\hline 18. & S18 & 14 & 11 & 13 & 38 & 76 \\
\hline 19. & S19 & 13 & 12 & 16 & 41 & 82 \\
\hline 20. & S20 & 12 & 12 & 12 & 37 & 74 \\
\hline 21. & $\mathrm{~S} 21$ & 11 & 12 & 12 & 35 & 70 \\
\hline 22. & $\mathrm{~S} 22$ & 13 & 12 & 13 & 37 & 74 \\
\hline 23. & $\mathrm{~S} 23$ & 12 & 12 & 13 & 37 & 74 \\
\hline \multirow[t]{5}{*}{24.} & S24 & 13 & 13 & 12 & 38 & 76 \\
\hline & $\begin{array}{r}\text { Jumlah hasil } \\
\text { belajar }\end{array}$ & 311 & 287 & 315 & 917 & 1.834 \\
\hline & ata-rata kelas & 12,96 & 11,96 & 13,13 & 38,05 & 76,1 \\
\hline & Nilai tertinggi & & & & & 94 \\
\hline & Jilai terendah & & & & & 54 \\
\hline
\end{tabular}

Selanjutnya pada hasil tes siklus 1 , diketahui nilai rata-rata kemampuan awal siswa dalam memahami teks berbahasa Inggris sebesar 76,1. Nilai minimal yang muncul pada tahap awal (pratindakan) adalah 54 dan nilai maksimal yang muncul adalah 94 . Sebelas orang siswa $(45,83 \%)$ belum mampu dalam mencapai nilai sesuai dengan kriteria ketuntasan minimal (KKM) untuk pelajaran bahasa Inggris dan tiga belas orang siswa $(54,17 \%)$ mampu mencapai nilai KKM. Pada siklus ini kohesi leksikal masih menjadi aspek dengan pencapaian terendah walaupun nilai rata-ratanya sudah mengalami peningkatan sebesar 1,46. Peningkatan pada siklus 1 juga dibuktikan dengan adanya peningkatan nilai siswa, yaitu nilai tertinggi pada tes pratindakan adalah 84 , sedangkan pada siklus 1 adalah 94 . Untuk itu, siswa perlu diberikan pemahaman yang lebih lagi dalam menguasai kohesi leksikal agar pada siklus 2 siswa mampu memahami bacaan dan menjawab soal dengan lebih baik lagi. 


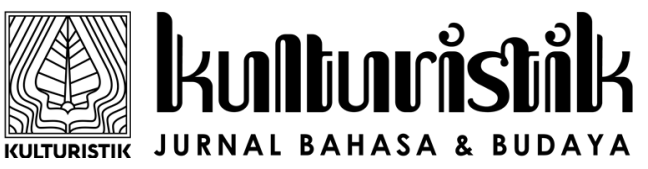

Vol. 3, No. 2, Juli 2019, 36

Available Online at https://ejournal.warmadewa.ac.id/index.php/kulturistik DOI: dx.doi.org/10.22225/kulturistik.3.2.1186

Tabel 3 Hasil Tes Evaluasi Belajar Siklus 2

\begin{tabular}{|c|c|c|c|c|c|c|}
\hline \multirow[b]{2}{*}{ No. } & \multirow[b]{2}{*}{ Nama } & \multicolumn{3}{|c|}{ Aspek } & \multirow[b]{2}{*}{ Skor } & \multirow[b]{2}{*}{ Nilai } \\
\hline & & Gramatikal & Leksikal & $\begin{array}{l}\text { Pemahaman ide } \\
\text { pokok bacaan }\end{array}$ & & \\
\hline 1. & $\mathrm{~S} 1$ & 15 & 15 & 19 & 49 & 98 \\
\hline 2. & S2 & 6 & 6 & 8 & 20 & 40 \\
\hline 3. & $\mathrm{~S} 3$ & 13 & 14 & 20 & 47 & 94 \\
\hline 4. & $\mathrm{~S} 4$ & 15 & 13 & 19 & 47 & 94 \\
\hline 5. & S5 & 15 & 14 & 19 & 48 & 96 \\
\hline 6. & S6 & 14 & 14 & 18 & 46 & 92 \\
\hline 7. & $\mathrm{~S} 7$ & 15 & 14 & 17 & 46 & 92 \\
\hline 8. & S8 & 13 & 14 & 14 & 41 & 82 \\
\hline 9. & S9 & 11 & 11 & 12 & 34 & 68 \\
\hline 10. & S10 & 11 & 11 & 13 & 48 & 96 \\
\hline 11. & S11 & 13 & 13 & 18 & 44 & 88 \\
\hline 12. & $\mathrm{~S} 12$ & 13 & 9 & 10 & 31 & 62 \\
\hline 13. & S13 & 13 & 14 & 15 & 45 & 90 \\
\hline 14. & S14 & 15 & 15 & 19 & 49 & 98 \\
\hline 15. & S15 & 14 & 13 & 12 & 47 & 94 \\
\hline 16. & S16 & 13 & 12 & 17 & 42 & 84 \\
\hline 17. & S17 & 14 & 13 & 18 & 45 & 90 \\
\hline 18. & $\mathrm{~S} 18$ & 15 & 14 & 19 & 48 & 96 \\
\hline 19. & S19 & 15 & 15 & 19 & 49 & 98 \\
\hline 20. & S20 & 15 & 14 & 20 & 49 & 98 \\
\hline 21. & $\mathrm{~S} 21$ & 13 & 10 & 15 & 38 & 76 \\
\hline 22. & $\mathrm{~S} 22$ & 15 & 14 & 20 & 49 & 98 \\
\hline 23. & $\mathrm{~S} 23$ & 12 & 10 & 7 & 29 & 58 \\
\hline \multirow[t]{5}{*}{24.} & S24 & 10 & 20 & 20 & 50 & 100 \\
\hline & $\begin{array}{r}\text { Jumlah hasil } \\
\text { belajar }\end{array}$ & 328 & 312 & 388 & 1041 & 2.082 \\
\hline & ata-rata kelas & 13,67 & 13 & 16,17 & 42,84 & 85,68 \\
\hline & Jilai tertinggi & & & & & 100 \\
\hline & Jilai terendah & & & & & 40 \\
\hline
\end{tabular}

Siswa memperoleh nilai rata $=$ rata dalam memahami teks berbahasa Inggris pada siklus 2 adalah 85,68. Nilai ini mengalami peningkatan 10,34 dari siklus 1 . Nilai minimal siklus 2 adalah 40 dan nilai maksimal adalah 100. Sebanyak 4 orang siswa $(16,67 \%)$ belum mampu mencapai nilai yang sesuai dengan kriteria ketuntasan minimal (KKM) untuk pelajaran bahasa Inggris. Jumlah ini sudah berkurang dari siklus 1 dan sebanyak 20 orang siswa (83,33\%) mampu mencapai nilai KKM, yaitu 75 ke atas. Pada siklus 2 ini pemahaman siswa sudah mulai terlihat, salah satu di antaranya ditunjukkan dengan nilai tertinggi yang diperoleh siswa, yaitu 100 ..

Berikut dideskripsikan hasil kemampuan siswa pada tahap awal dalam memahami teks berbahasa Inggris yang dilakukan pada tiga aspek penilaian, yaitu :

\section{Aspek Gramatikal}

Dalam tahap awal/pratindakan, didapatlan bahwa jumlah hasil rata-rata kelas pada aspek ini sebesar 67,83. Dari ketiga aspek penilaian, aspek kohesi leksikal mendapatkan capaian terendah, yaitu 252. Dengan jumlah soal kohesi 
Vol. 3, No. 2, Juli 2019, 37

Available Online at https://ejournal.warmadewa.ac.id/index.php/kulturistik DOI: dx.doi.org/10.22225/kulturistik.3.2.1186

leksikal sebanyak lima belas dari total keseluruhan lima puluh soal, nilai terendah diperoleh oleh S6 dan S7 dengan jumlah soal yang dapat diselesaikan hanya delapan soal. Sebaliknya nilai tertinggi diperoleh S11, S14, S17 dengan hanya ada kesalahan sebanyak 2 soal. Berdasarkan hasil di atas dapat disimpulkan bahwa aspek gramatikal perlu ditingkatkan kembali sehingga diperoleh nilai yang lebih baik lagi.

\section{Aspek Leksikal}

Aspek leksikal merupakan aspek yang memiliki jumlah kesalahan terbanyak pada tahap pratindakan. Rata-rata kelas pada aspek ini, yaitu 10,5 dengan total soal yang diberikan adalah lima belas soal. Skor terendah pada aspek ini diperoleh oleh S8, S9, S21 dengan hanya delapan jawaban benar, sedangkan skor yang tertinggi diperoleh oleh S1 karena tidak dapat menjawab satu soal saja.

\section{Pemahaman Isi Bacaan}

Pada aspek ini, diraih rata-rata kelas sebesar 13,12 . Skor terendah pada aspek ini diperoleh oleh S8 dan skor tertinggi diperoleh oleh S1, S2, S3, dan S22. Total soal pada aspek ini adalah dua puluh soal dan terbanyak dibandingkan dengan kedua aspek lainnya. Hal ini dimaksudkan agar siswa memberikan perhatian lebih pada aspek ini karena siswa sangat tidak menikmati kegiatan membaca yang dilakukan di samping itu, menjawab soal berdasarkan teks merupakan hal yang membosankan untuk mereka.

Dari kemampuan membaca pemahaman siswa diperoleh hasil tes pratindakan dengan rerata sebesar 67,83. Sejumlah 6 siswa mendapat nilai mulai dari dan di atas 75, sedangkan 18 siswa memperolej nilai kurang dari 75. Nilai 75 adalah nilai kriteria ketuntasan minimal (KKM) yang sudah ditetapkan pada kurikulum sekolah SMA Jembatan Budaya. Hasil tes yang diperoleh siswa, bermaksud digunakan oleh guru sekaligus peneliti dalam memperbaiki dan meningkatkan kemampuan membaca pemahaman siswa yang terbukti masih belum optimal. Usaha dalam peningkatan dan perbaikan kemampuan siswa ini akan menggunakan penerapan metode CIRC>

Data awal kemampuan siswa dalam membaca pemahaman yang telah diperoleh dari tes pratindakan dan hasil prasurvei terhadap proses pembelajaran membaca, menjadi bekal untuk nantinya di susun rencana perbaikan pembelajaran yang akan digunakan sebagai acuan dan arahan dalam peningkatan kemampuan membaca siswa.

Rencana perbaikan pembelajaran yang di susun dengan mengacu kepada hasil tes awal siswa diharapkan dapat memudahkan siswa yang tadinya mengalami kesulitan dalam kegiatan membaca pemahaman dan kurang tertarik dalam mengikuti proses pembelajaran, diharapkan nantinya dapat mengikuti kegiatan pembelajaran dengan lebih baik dan lebih tertarik pada proses pemblejaran serta menjadi siswa yang lebih aktif dalam berpartisipasi mengikuti kegiatan pembelajaran. Rencana perbaikan pembelajaran ini juga diharapkan memberikan petunjuk dalam membantu siswa yang belum mampu mencapai standar kriteria ketuntasan minimal yang ditetapkan oleh kurikulum sekolah sehingga nantinya kesuksesan dapat dicapai di kemudian hari.

Kemampuan Siswa dalam Memahami Kohesi Leksikal dan Kohesi Gramatikal Setelah Penerapan Metode CIRC di Kelas XI IPA 3 SMA Jembatan Budaya

Penelitian tindakan kelas yang dilakukan dalam proses pembelajaran mem- 


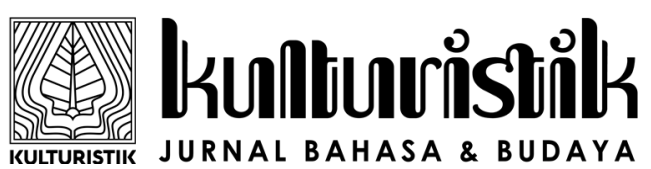

Vol. 3, No. 2, Juli 2019, 38

Available Online at https://ejournal.warmadewa.ac.id/index.php/kulturistik DOI: dx.doi.org/10.22225/kulturistik.3.2.1186

baca pemahaman siswa kelas XI IPA 3 SMA Jembatan Budaya dirancang menggunakan dua siklus. Siklus pertama dilakukan mulai 11 - 25 Januari 2016 dan dilakukan dalam tiga sesi, sedangkan siklus kedua dilaksanakan pada 1 Februari 2016 dan tanggal 15 Februari 2016. Penelitian tindakan kelas ini dilaksanakan pada semester II, disesuaikan dengan materi yang terdapat pada kurikulum pembelajaran yang digunakan pada semester II.

Pada metode CIRC, kegiatan pembelajaran harus dilakukan dalam kelompok. Pembagian kelompok ini sebaiknya dilakukan sebelum pembelajaran dilaksanakan dan dibagi oleh guru sehingga pembagian akan lebih adil dan merata. Tidak lupa juga untuk selalu engacu pada tingkat kemampuan membaca pemahaman siswa pada saat tes pratindakan.

Tabel 4 Perbandingan Nilai Rata-rata Pratindakan dan Siklus I

\begin{tabular}{clccc}
\hline No. & $\begin{array}{c}\text { Aspek-Aspek } \\
\text { Penilaian }\end{array}$ & Pratindakan & Siklus 1 & Siklus 2 \\
\hline 1. & Gramatikal & 10,67 & 12,96 & 13,67 \\
2. & Leksikal & 10,5 & 11,96 & 13 \\
3. & Pemahaman Bacaan & 13,12 & 13,13 & 16,17 \\
& $\quad$ Jumlah & 34,29 & 38,05 & 42,84 \\
\hline
\end{tabular}

Berdasarkan tabel perbandingan nilai sebelumnya, telah ditunjukkan bahwa nilai rata-rata setiap aspek penilaian meningkat pada kegiatan awal atau pratindakan dan siklus I. Aspek pada siklus I meningkat dengan jumlah yang paling jelas. Perbandingan perolehan jumlah hasil belajar pratindakan dan siklus I dapat dilihat pada diagram di bawah ini

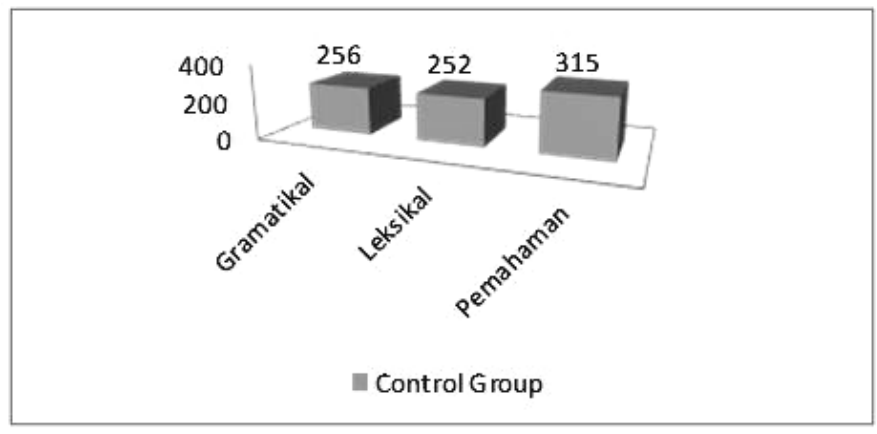

Diagram 1 Pretest

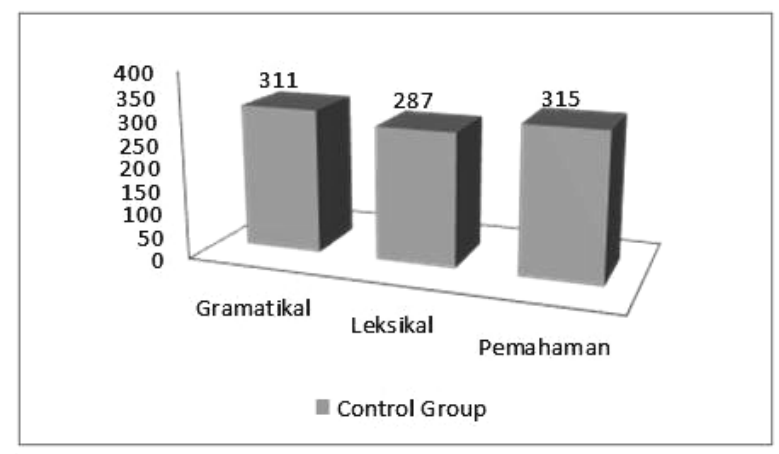

Diagram 2 Siklus 1 


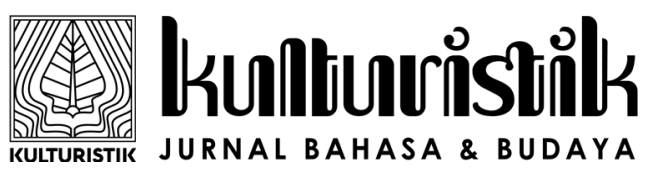

Vol. 3, No. 2, Juli 2019, 39

Available Online at https://ejournal.warmadewa.ac.id/index.php/kulturistik DOI: dx.doi.org/10.22225/kulturistik.3.2.1186

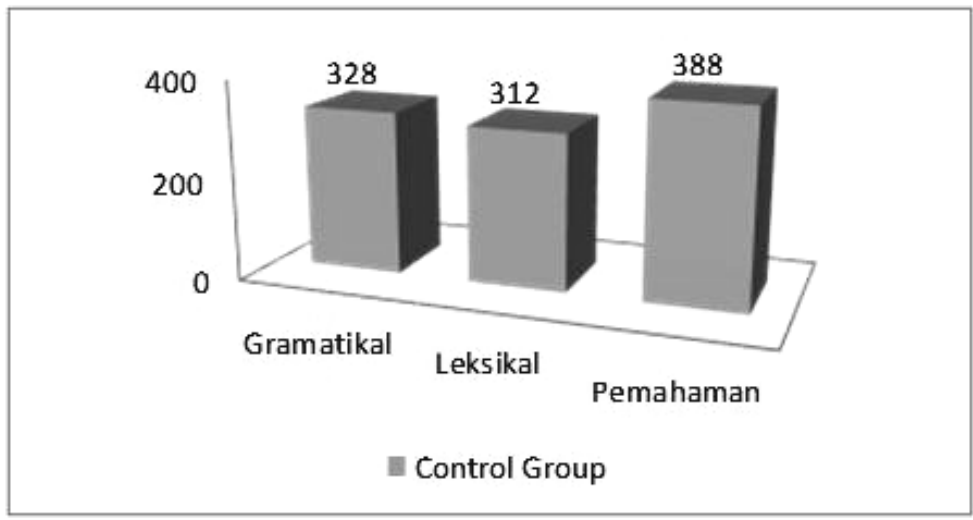

Diagram 3 Siklus 2

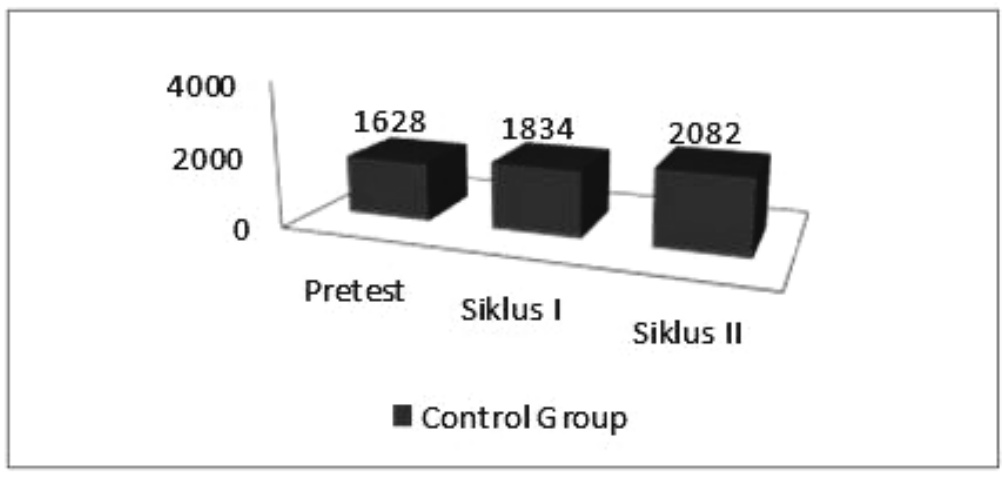

Diagram 4 Perbandingan Nilai Rata-Rata Pretest dan Tiap Siklus

\section{SIMPULAN}

Hasil penelitian dan pembahasan yang telah dipaparkan diatas menyimpulkan bahwa kemampuan membaca pemahaman siswa kelas XI IPA 3 SMA Jembatan Budaya dapat ditingkatkan melalui metode CIRC. Selain memiliki proses pembelajaran yang lebih menarik dan menyenangkan, peningkatan terhadap kemampuan siswa dalam memahami teks juga dilihat dari perbandingan nilai ratarata tes membaca pemahaman siswa pada tahap pratindakan, dibandingkan juga dengan pascatindakan siklus 1 dan pascatindakan siklus 2. Peserta didik memperoleh nilai rata-rata tes membaca pemahaman pada tahap pratindakan sebesar 61,58. Lalu pada nilai rata-rata tes membaca pemahaman pada siklus 2 meningkat sebesar 81,58. Jadi, terjadi peningkatan rata-rata sebesar 20,00. Dari data hasil penelitian dan pembahasan yang telah dipaparkan di atas, dapat disimpulkan bahwa penggunaan metode CIRC dalam pembelajaran membaca pemahaman mampu meningkatkan kemampuan membaca pemahaman siswa kelas XI IPA 3 SMA Jembatan Budaya.

\section{DAFTAR PUSTAKA}

Alderson, J. C. (2000). Assesing Reading. Cambridge: Cambridge.

Arbainsyah. (2008). Penerapan Pendekatan Konstruktivisme untuk Meningkatkan 
Kemampuan Membaca Pemahaman Interpretatif Siswa. Jurnal Kependidikan, $1(1)$.

Carr, A. A., Jonassen, D. H., Litzinger, M. E., \& Marra, R. M. (1998). Good Ideas to Foment Educational Revolution: The Role of Systemic Change in Advancing Situated Learning, Constructivist, and Feminist Pedagogy. Educational Technology, 38(1), 5-15.

Eriyanto. (2001). Analisis Wacana: Pengantar Analisis Teks Media. Yogyakarta: Percetakan LKIS.

Goodman, K. S. (1996). On Reading. Portsmourth, NH: Heineman.

Hibbard, K. M. (2003). Assesing and Teaching Reading Comprehension and Writing, 3-5. UK: Routledge.

Luxemburg, \& Et.al. (1992). Penghantar Ilmu Sastra. Jakarta: Gramedia Pustaka Utama.

Mulyani, H. (2009). Konsepsi Kesempurnaan Hidup dalan Teks Serat Pasthikamaya. Universitas Negeri Yogyakarta.

Slavin, R. E. (2005). Cooperative Learning, Teori, Riset dan Praktik. Bandung: Nusa Media.

Sobur, A. (2004). Semiotika Komunikasi. Bandung: Remaja Rosdakarya.

Sutarno, \& Dkk. (2010). Penerapan Model Pembelajaran Cooperative Integrated Reading and Composition (CIRC) Berbasis Komputer untuk Meningkatkan Hasil Belajar Siswa pada Pembelajaran TIK. Jurnal PTIK, 3(1), 1-5.

Tarigan, H. G. (2008). Membaca Sebagai Suatu Keterampilan Berbahasa. Bandung: Angkasa.

Titscher, S. (2009). Methods of Text and Discourse Analysis. London: Sage. 